\title{
Patterns of Refsum's disease
}

\author{
Phytanic acid oxidase deficiency
}

\begin{abstract}
A POUlos, A C POllard, J D MITCHEll, G WISE, AND G MORTIMER
Department of Chemical Pathology, The Adelaide Children's Hospital and Prince of Wales Children's Hospital, New South Wales, Australia, and the Department of Pediatrics, University of Dunedin, New Zealand
\end{abstract}

SUMMARY Four children each exhibiting a profound deficiency of phytanic acid oxidase activity in cultured skin fibroblasts but with very different phenotypes, are described. A consistently raised plasma phytanic acid value, generally considered to be pathognomonic for Refsum's disease (phytanic acid oxidase deficiency), was observed in three of these children but not in the fourth, who also showed no evidence of accumulation of phytanic acid in liver or fat biopsies. Our data suggest that the clinical diagnosis of Refsum's disease in children is more difficult because the full spectrum of clinical features usually observed in adults with the disorder is not always present. Moreover, a failure to detect a raised plasma phytanic acid value may not necessarily indicate normal fibroblast phytanic acid oxidase activity.

Refsum's disease is an inherited disorder of phytanic acid (3, 7, 11, 15-tetramethylhexadecanoic acid) metabolism, ${ }^{1}$ and seems to be caused by a defect in the enzymatic oxidation of phytanate. The classic clinical features are cerebellar ataxia, retinitis pigmentosa, and peripheral neuropathy. ${ }^{2}{ }^{3}$ The age of onset may vary from early childhood to the fourth or fifth decade ${ }^{3-5}$ In most cases, however, the more serious clinical features do not develop till at least the second decade of life. Because of this, diagnosis is not commonly made in childhood, although recognition of the defect would facilitate early dietary treatment, possibly reducing the likelihood of irreversible neurological damage.

Biochemical diagnosis of the disorder can be made by the finding of the characteristic, raised phytanic acid value in plasma. In addition, a defect in phytanic acid oxidase, a mitochondrial enzyme that initiates the catabolism of phytanic acid, can be shown in fibroblasts. ${ }^{6-8}$ For practical reasons, however, these enzyme tests have not been widely used as a means of confirming the diagnosis.

We describe four patients of widely differing phenotypes who presented early in childhood, none of whom displayed all the clinical features normally associated with the adult form of Refsum's disease. Although a phytanic acid oxidase deficiency in fibroblasts was observed in all patients, a consistently raised plasma phytanate value was found in only three. Our results suggest that classical Refsum's disease is only one particular phenotypic form of expression of inherited phytanic acid oxidase deficiency.

\section{Materials and methods}

Unlabelled phytanic acid and $1-{ }^{14} \mathrm{C}$ stearic acid were obtained from Applied Science Laboratories (USA) and Amersham (UK), respectively. $1-{ }^{14} \mathrm{C}$ phytanic acid was prepared as described previously. ${ }^{9}$

The culture conditions used and the assay of phytanic acid oxidase activity of cultured skin fibroblasts have been described. ${ }^{10}$ Stearic acid oxidase activity was measured as described for phytanic and oxidase activity ${ }^{10}$ except for the substitution of $\left[1-{ }^{14} \mathrm{C}\right]$ stearic acid for $\left[1-{ }^{14} \mathrm{C}\right]$ phytanic acid. Because of the poor binding of the substrate to the fetal calf serum the following modification was necessary: $\left[1{ }^{14} \mathrm{C}\right]$ stearic acid $(1.4 \mu \mathrm{mol}, 4 \mu \mathrm{Ci})$ was incubated with $1.4 \mathrm{ml}$ of a $50 \mathrm{mg} / \mathrm{ml}$ aqueous solution of delipidated bovine serum albumin at $37^{\circ} \mathrm{C}$ for 30 minutes after the addition of $20 \mu \mathrm{l} 70 \mathrm{mmol} / \mathrm{l}$ sodium hydroxide solution; $0.6 \mathrm{ml}$ fetal calf serum and $8 \mathrm{ml}$ basal Eagle's medium were then added, and after vortexing vigorously the mixture was passed through a $\mathbf{0 . 2} \mu$ Millipore filter. Under these conditions an average of 40 to $50 \%$ of the label passed through the filter. The ${ }^{14} \mathrm{CO}_{2}$ produced was measured as 
described ${ }^{10}$ four days after the introduction of $0.4 \mathrm{ml}$ of filtrate (22 to $28 \mathrm{nmol}$ substrate) into flasks containing confluent cell cultures $(0.3$ to $0.5 \mathrm{mg}$ total protein). Plasma total phytanate was measured as described by Phillipou and Poulos. ${ }^{11}$ Erythrocyte phytanate was determined in the following manner: 5 to $10 \mathrm{ml}$ heparinized blood was centrifuged at 500 $g$ for 30 minutes at $4^{\circ} \mathrm{C}$. After removing the plasma, the red cell pellet was made up to the original blood volume with deionised water; $1.0 \mathrm{ml}$ of this lysate was then refluxed with $20 \mathrm{ml}$ chloroform-methanol $(2: 1, v / v)$ for 30 minutes. The mixture was filtered through chloroform-methanol $(1: 1, \mathrm{v} / \mathrm{v})$ washed Whatman No 1 filter paper and the filtrate retained. The residue was refluxed first with $20 \mathrm{ml}$ chloroform-methanol $(1: 1, \mathrm{v} / \mathrm{v})$ for 30 minutes, and then with $20 \mathrm{ml}$ chloroform-methanol $(1: 9, \mathrm{v} / \mathrm{v})$ for a further 30 minutes. The mixture was filtered again as before, and the chloroform-methanol-water composition of the combined filtrates was adjusted to 8:4:3 v/v, by adding appropriate amounts of water and chloroform. Lipids were then recovered from the solvent mixture by a standard partitioning method. ${ }^{12}$ Quantitation of the long chain fatty acids was performed in a similar manner to that described for the plasma. Combined chemical ionisation mass spectrometric analysis of the fatty acid methyl esters was performed with a Hewlett Packard 5982 A quadrupole mass spectrometer and data system, using methane as both carrier and reagent gas. The methyl phytanate $(\mathrm{M}+1)^{+}$ion $(\mathrm{m} / \mathrm{z} 327)$ was detected using the mass spectrometer in the selected ion monitoring mode.

\section{Patients}

Case 1. A 7 year old boy who had been fostered and for whom no family history was available presented at 4 months of age to the Prince of Wales Children's Hospital with left sided fits, left hemiplegia, right subdural haematoma, vitamin $\mathrm{K}$ responsive coagulation defects, hepatosplenomegaly, and laboratory evidence of mild anicteric hepatocellular dysfunction. The subdural haematoma was successfully drained. At age 10 months the clinical findings included generalised hypotonia and hyporeflexia, retinitis pigmentosa with severe visual difficulty and mild microphthalmia, and delayed development. Biopsies of liver and rectal mucosae were histologically normal as were motor and sensory nerve conduction velocities. His plasma phytanate value was raised $(5 \mathrm{mg} / 100 \mathrm{ml}$, normal $<0.5 \mathrm{mg} / 100 \mathrm{ml})$. His subsequent progress was slow with persisting severe visual and hearing difficulties; speech development was (and has remained) limited to a few words only. Independent walking was delayed until 3 years of age. At 4 years of age nerve conduction velocities were still normal and the plasma phytanate value had risen to $20 \mathrm{mg} / 100 \mathrm{ml}$. Further investigation at age $5 \frac{1}{2}$ years, prompted by increasing irritability and self mutilating behaviour, showed that nerve conduction velocities had become reducedcommon peroneal conduction velocity was 31.9 $\mathrm{m} / \mathrm{second}$ and median motor conduction velocity was $34 \mathrm{~m} / \mathrm{second}$. A sural nerve biopsy showed a mild reduction in the myelinated fibres and teased fibres showed segmental demyelination. Total plasma phytanate remained at $20 \mathrm{mg} / 100 \mathrm{ml}$. Total plasma cholesterol was low $(2 \cdot 14 \mathrm{mmol} / 1$, normal range 3.6 to $6.2 \mathrm{mmol} / \mathrm{l}$ between 1 and 14 years). At this time the liver was only just palpable, but showed minor non-specific histological changes on light microscopy. Dietary treatment designed to limit phytanate intake ${ }^{813}$ began when the patient was aged 6 years. His plasma phytanate concentration fell rapidly to $2.3 \mathrm{mg} / 100 \mathrm{ml}$ and this was accompanied by a striking improvement in mood and behaviour. So far, however, after 6 months treatment, there has been no objective proof of improvement in hearing, sight, or motor function.

Case 2. This patient, who also presented to the Prince of Wales Children's Hospital, is a 7 year old boy of average height and is the only child of unrelated parents. At 4 months of age he developed a three week illness characterised by jaundice and hepatosplenomegaly. Liver biopsy showed a nonspecific hepatitis for which no definite cause could be determined. Further investigation was prompted at 2 years of age because of delay in walking. At this time hypotonia, muscle weakness, and absent reflexes in the lower limbs were noted. There was noticeable liver enlargement with mild splenomegaly; nerve conduction velocities were impairedcommon peroneal conduction velocity, $10 \mathrm{~m} /$ second; absent sural nerve conduction velocity; median motor conduction velocity, $22 \mathrm{~m}^{2} / \mathrm{second}$; absent median sensory conduction velocity; and sural and median sensory nerve action potential were not detectable. A sural nerve biopsy showed demyelination. Schwann cells contained unstructured inclusions as well as excess numbers of vacuoles. These latter findings were both compatible with a severe demyelinating neuropathy. The optic fundi and vision were normal. Plasma phytanate was $1.6 \mathrm{mg} / 100 \mathrm{ml}$.

A repeat liver biopsy at 4 years of age showed considerable portal tract fibrosis and intralobular septa formation, but little suggestion of active inflammation. Many hepatocytes were enlarged and variably stained. Macrophage like cells containing coarse filaments and granules of periodic acid Schiff 
positive material were present in the portal tracts. At the age of 6 years he could walk at a brisk pace, but with a broad based, knee locking gait. There was mild distal weakness in the upper limbs, absent reflexes in both upper and lower limbs, and bilateral pes cavus. Hearing, vision, and optic fundi were normal. His liver and spleen were no longer palpable, and biochemically liver function was normal. A further liver biopsy showed changes similar to those observed two years earlier. His plasma phytanate value was normal (even though his diet had not been noticeably deficient in phytanic acid or phytol) and has remained so since. The total plasma cholesterol concentration was low $(3.08 \mathrm{mmol} / \mathrm{l})$. His mother also showed clear evidence of a peripheral neuropathy, with pes cavus, a mild distal weakness in the upper limbs, absent reflexes, and slowed nerve conduction velocities (common peroneal conduction velocity, $34 \mathrm{~m} / \mathrm{second}$; sural conduction velocity, absent; sural nerve action potential, not detectable; median sensory nerve action potential, 3 microvolts). The mother refused a nerve biopsy, but had normal hearing and vision, a normal plasma phytanate value, and normal skin fibroblast phytanic acid oxidase $(23 \mathrm{pmol} / \mathrm{h} / \mathrm{mg})$. The patient's father refused to be examined or to have electrical studies performed.

Case 3. This 9 year old boy presented in 1982 in Dunedin with sudden onset of heart failure. His mother had noted, however, that he had lacked coordination and had had a progressively unstable gait from about the age of 5 years. On examination a cardiomyopathy with substantial heart enlargement was observed, his skin was dry and scaly in patches, ankle and knee jerks were absent, and motor nerve conduction velocities were greatly reduced. On fundoscopic examination the retinae were unusually pale but did not show the classic changes associated with retinitis pigmentosa; electroretinograms, however, were clearly normal. His plasma phytanate value was very high $(198 \mathrm{mg} / 100 \mathrm{ml})$, while his total plasma cholesterol value was normal $(4.33$ $\mathrm{mmol} / \mathrm{l})$. Dietary treatment and plasmaphoresis 814 were begun immediately and his plasma phytanate value fell to $57 \mathrm{mg} / 100 \mathrm{ml}$ within three months.

Case 4. This 6 year old boy was the second child of unrelated parents. There was no family history of inherited metabolic disease. He presented initially with a mild neonatal jaundice and seemed to develop normally till the age of 7 months, when he had a seizure after a febrile illness. Between the ages of 9 months and 2 years he had a further half dozen febrile seizures. During this period speech did not develop and his behaviour became increasingly difficult. He first walked at 17 months, but did so on tip toes. A severe bilateral sensory neural hearing loss was diagnosed at 3 years, At 5 years there were no dysmorphic features apart from a slightly coarse facial appearance. His height, weight, and head circumference were all at, or about, the 50 th centile. He was hyperactive, aggressive, without speech, and was given to self mutilation, but tone, reflexes, and strength seemed to be normal. There was no evidence of retinitis pigmentosa; the liver and spleen were not palpable; and his plasma phytanate value, when first measured at this age, was raised $(2 \mathrm{mg} / 100 \mathrm{ml})$.

Nerve conduction studies performed at the age of 6 years showed evidence for a diffuse polyneuropathy (right sural sensory nerve action potential, absent; right common peroneal motor conduction velocity, $35 \mathrm{~m} / \mathrm{second}$; and left posterior tibial motor conduction velocity $27.9 \mathrm{~m} / \mathrm{second})$. A sural nerve biopsy showed a decrease in the number of myelinated nerve fibres without any 'onion bulb' formation: electron microscopy confirmed the demyelinating neuropathy but did not show any inclusions. Plasma phytanate was still raised $(1.5 \mathrm{mg} / \mathrm{ml})$ and his total plasma cholesterol concentration was low (2.96 $\mathrm{mmol} / \mathrm{l})$.

\section{Results}

A summary of the major clinical features and phytanic acid data from these four children is given in Table 1, together with the corresponding summary data from three of our recent adult patients for comparison. The plasma phytanate value in case 3 was very much higher than that found at presentation in any of the other children studied, or in any of the adult patients with Refsum's disease. The plasma phytanate concentration increased with age in case 1 ; in case 2 , however, it decreased, without specific treatment, to normal values by the age of 4 years. The erythrocyte phytanate value was raised in cases 1 and 4 , it was even higher in case 3 , but by the methods employed, it was not distinguishable from normal (not detectable) in case 2. Dietary treatment coupled with plasmaphoresis reduced the plasma phytanate value in case 3 considerably, but dietary restriction alone had a similar effect in case 1 .

Fibroblast lines from each of the four children showed gross impairment in the ability to oxidase phytanate- the impairment being comparable to that shown by fibroblasts from each of the unequivocal adult patients with Refsum's disease (Table 2). By contrast, the ability of the cells to oxidase a straight chain fatty acid substrate, stearic acid, was moderately reduced in cases 1 and 2 (10 and $12 \mathrm{pmol} / \mathrm{h} / \mathrm{mg}$ protein respectively, controls $>22$ 
Table 1 Plasma and erythrocyte phytanate in Refsum's disease

\begin{tabular}{|c|c|c|c|c|c|}
\hline \multirow[t]{2}{*}{ Case No } & \multirow{2}{*}{$\begin{array}{l}\text { Major clinical features } \\
\text { at most recent clinical } \\
\text { examination }\end{array}$} & \multicolumn{2}{|l|}{ Age } & \multirow{2}{*}{$\begin{array}{l}\text { Plasma } \\
\text { phytanate value } \\
(\mathrm{mg} / 100 \mathrm{ml})\end{array}$} & \multirow{2}{*}{$\begin{array}{l}\text { Erythrocyte } \\
\text { phytanate } \\
\text { (\% of total } \\
\text { fatty acids) }\end{array}$} \\
\hline & & $\begin{array}{l}\text { At presentation } \\
\text { (years) }\end{array}$ & $\begin{array}{l}\text { At time of } \\
\text { phytanate } \\
\text { determination } \\
\text { (years) }\end{array}$ & & \\
\hline \multicolumn{6}{|l|}{ Children } \\
\hline 1 & $\begin{array}{l}\text { Motor and intellectual impairment, } \\
\text { retinitis pigmentosa, deafness, } \\
\text { hepatic abnormalities }\end{array}$ & 1 & $\begin{array}{l}1 \\
4 \\
5 \cdot 5 \\
7\end{array}$ & $\begin{array}{l}5 \\
20 \\
15 \\
2 \cdot 3^{*}\end{array}$ & $\begin{array}{l}\text { nd } \\
1 \cdot 3 \\
1 \cdot 0 \\
\text { nd }\end{array}$ \\
\hline 2 & $\begin{array}{l}\text { Peripheral neuropathy, pes cavus, } \\
\text { hepatic abnormalities }\end{array}$ & $0 \cdot 3$ & $\begin{array}{l}2 \\
4 \\
6\end{array}$ & $\begin{array}{l}1 \cdot 6 \\
<0 \cdot 5 \\
<0 \cdot 5\end{array}$ & $\begin{array}{l}\text { nd } \\
\text { nd } \\
0 \cdot 1\end{array}$ \\
\hline 3 & $\begin{array}{l}\text { Cardiomyopathy, peripheral } \\
\text { neuropathy, cerebellar ataxia, } \\
\text { ichthyosis }\end{array}$ & 9 & $\begin{array}{l}9 \\
9\end{array}$ & $\begin{array}{l}189 \\
57^{*}\end{array}$ & $\begin{array}{l}15.2 \\
\text { nd }\end{array}$ \\
\hline 4 & $\begin{array}{l}\text { Intellectual impairment, } \\
\text { peripheral neuropathy, epilepsy, } \\
\text { deafness }\end{array}$ & 5 & $\begin{array}{l}5 \\
6\end{array}$ & $\begin{array}{l}2 \cdot 0 \\
1 \cdot 5\end{array}$ & $\begin{array}{l}\text { nd } \\
\text { nd }\end{array}$ \\
\hline \multicolumn{6}{|l|}{ Adults } \\
\hline A1 & $\begin{array}{l}\text { Peripheral neuropathy, cerebellar } \\
\text { ataxia, retinitis pigmentosa }\end{array}$ & & $\begin{array}{l}29 \\
30 \\
32\end{array}$ & $\begin{array}{l}22 \\
39 \\
55\end{array}$ & $\begin{array}{l}\text { nd } \\
\text { nd } \\
1 \cdot 5\end{array}$ \\
\hline A2 & $\begin{array}{l}\text { Peripheral neuropathy, cerebellar } \\
\text { ataxia, retinitis pigmentosa }\end{array}$ & & 26 & 26 & nd \\
\hline A3 & $\begin{array}{l}\text { Peripheral neuropathy, cerebellar } \\
\text { ataxia, deafness, retinitis } \\
\text { pigmentosa, late cardiomyopathy }\end{array}$ & & 34 & 135 & nd \\
\hline Normal range ${ }^{\dagger}$ & & & & $<0.5$ & $<0 \cdot 1$ \\
\hline
\end{tabular}

* These values were obtained after the introduction of a low phytanate diet.

+ Normal values were derived from subjects of all ages and both sexes. As the figure shown represents the limit detectable by packed column gas chromatography it is probable that the actual range is lower than this. nd=not done.

Table 2 Fibroblast phytanic acid oxidase activities in patients with Refsum's disease

\begin{tabular}{ll}
\hline Case no & $\begin{array}{l}\text { Phytanic acid oxidase activity* } \\
\text { (pmol/h/mg protein) }\end{array}$ \\
\hline Children & \\
1 & 2 \\
2 & 4 \\
3 & 4 \\
4 & 4 \\
Adults & \\
A1 & 2 \\
A3 & 5 \\
A2 & 4 \\
\hline
\end{tabular}

* Normal range $(\mathrm{n}<20) \quad 23-87 \mathrm{pmol} / \mathrm{h} / \mathrm{mg}$ protein.

$\mathrm{pmol} / \mathrm{h} / \mathrm{mg}$ protein) but not in cases 3 and 4 . The presence of phytanate is not detectable in normal liver and subcutaneous fat by our routine gas chromatographic methods $(<0.1 \mathrm{mg} / \mathrm{g}$ wet weight of tissues), but in case 1 the liver contained $1.7 \mathrm{mg} / \mathrm{g}$ shown by mass spectrometry. Phytanate was not detectable in the liver of case 2 . Somewhat surprisingly, subcutaneous fat from both case 1 and case 2 failed to show a raised phytanic acid value; mass spectrometric analysis of the extracts confirmed the presence of phytanic acid in similar amounts to those found in necropsy specimens obtained from a number of children.

The most striking feature in the electron microscopy of the liver in case 1 was the widespread occurrence of elongated lamellar profiles within many hepatocytes, Kupfer cells, and other macrophage type cells. These lamellar structures were trilaminar, 7-10 $\mathrm{nm}$ in width, with a clear central space between two dense outlines, and all three zones were approximately equal in width (Figure (a) and (b)). Lamellar profiles were most abundant within single membrane bound organelles resembling lysosomes that often contained one or multiple dense bodies of variable size. In this location lamellar profiles often occurred as a massed parallel array converging to a spindle point at opposite poles (Figure (b)). Although lamellar profiles were found free in the cytoplasm, they were few in number, dispersed irregularly, but situated close to lysosome like organelles containing similar structures. Hepatocytes frequently contained increased numbers of clear vesicles, distended cysternae of endoplasmic reticulum, and many showed 


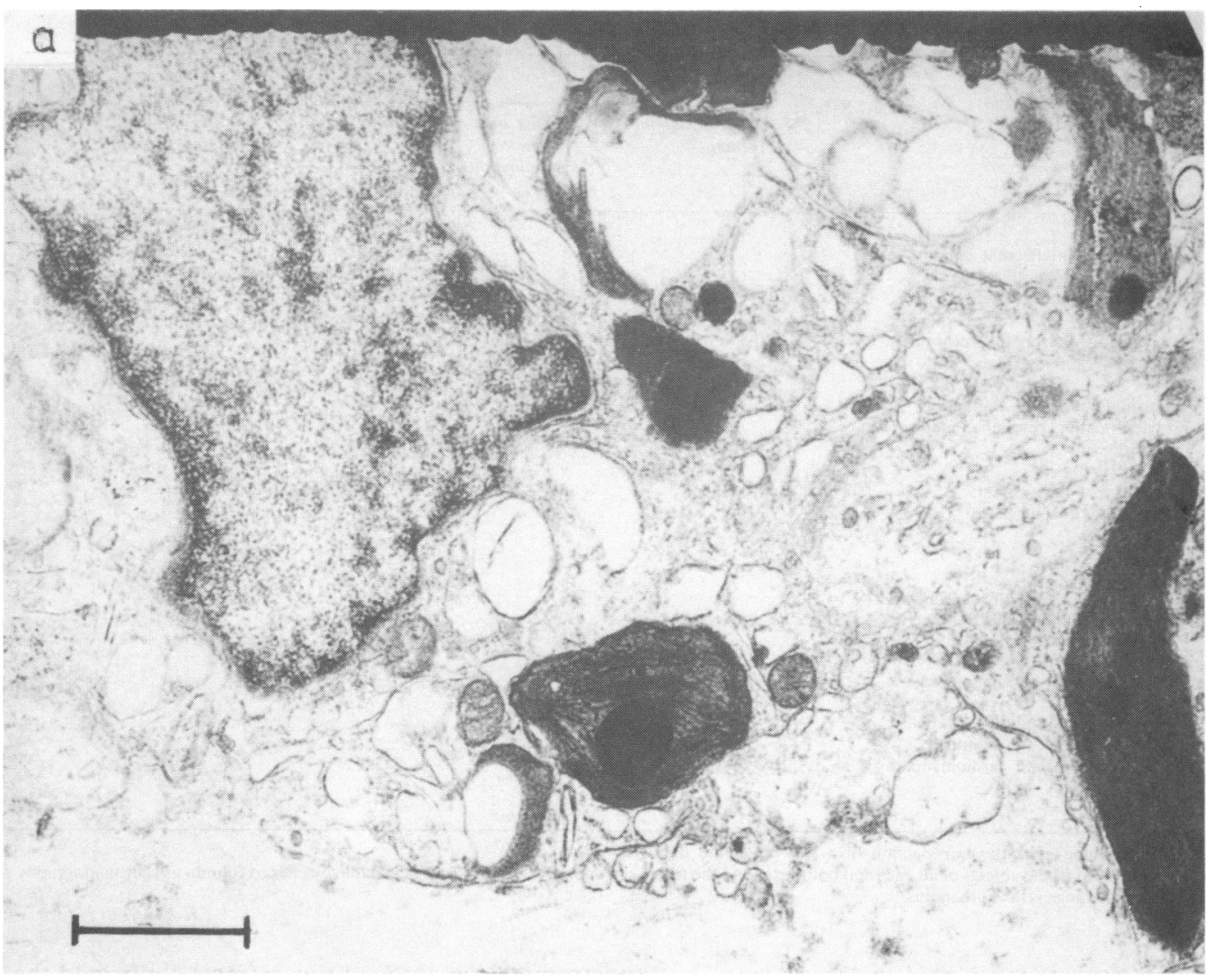

Figure Electron microscopy of liver biopsy in case 1.

(a) Magnification of hepatocyte showing portion of a nucleus, distended endoplasmic reticulum, clear vesicles, and two lysosome like organelles containing dense bodies and massed parallel arrays of trilaminar profiles. Scale marker denotes $1000 \mathrm{~mm} .(\times 20000)$.

large intranuclear collections of monoparticulate glycogen. Liver electron microscopy in case 2 showed non-specific intracellular abnormalities, with no lamellar profile structures being seen.

\section{Discussion}

In previous reports, patients with the major clinical features of Refsum's disease who have raised plasma phytanate values, have had a considerably reduced phytanic acid oxidase activity in cultured skin fibroblasts. ${ }^{610} 15$ Clinically similar patients deficient in phytanic acid oxidase but who do not accumulate phytanic acid in their plasma have not, as far as we are aware, been reported. The fibroblasts from all four of our children showed a similar level of residual phytanic acid oxidase activity to adults with clinically and biochemically confirmed Refsum's disease. The inability to confirm a consistently raised plasma phytanate value on case 2 nevertheless calls into question the propriety of the diagnosis of Refsum's disease in this child and prompted us to examine more closely the phytanate content of the tissues. No significant increase was observed in the liver of case 2, whereas in case 1 there was an increased amount of phytanate in the liver and the plasma phytanate value was also persistently raised. Neither of these children showed excessive accumulation of phytanate in subcutaneous fat.

Because of the neurological deficits observed in the mother of case 2, provisional diagnosis of either Charcot-Marie-Tooth or Dejerine-Sottas disease, both of which may be inherited as autosomal dominant traits, ${ }^{16}$ were considered first. The finding of phytanate oxidase deficiency in the son raised doubts, however, about these diagnoses. The possi- 


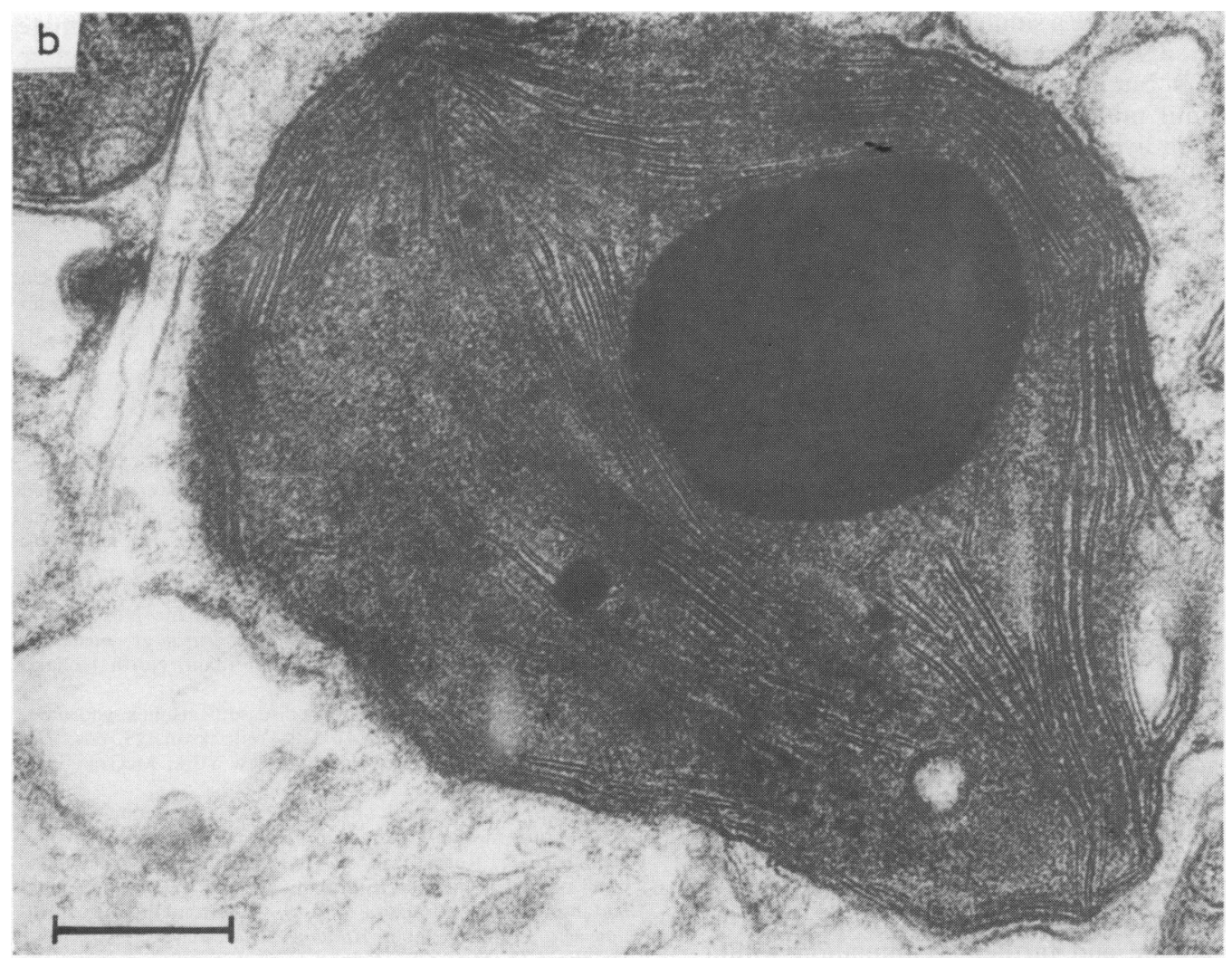

(b) Detail of a lysosome like organelle from (a) showing a massed parallel array of lamellar structures converging at opposite poles. One large and multiple smaller dense bodies are present and a single limiting membrane can be seen surrounding much of the organelle. Scale marker denotes $200 \mathrm{~mm}$. (×100 000).

bility that fibroblast lines had become mislabelled was also considered, but a fresh culture from a second skin biopsy showed the same phytanic acid oxidase deficiency as before. It is possible that the unique phenotype of this patient reflects the inheritance of two sets of mutant genes, one for Refsum's disease and the other for Charcot-Marie-Tooth disease. On the other hand the observed defect may represent a secondary phenomenon caused by some other gene product. What is not clear, however, is why, if the deficiency was present in vivo, it did not lead to a permanent increase in plasma or tissue phytanate concentrations.

The clinical presentation of cases, 1,2 , and 4 was not particularly suggestive of Refsum's disease, and case 3, although reasonably typical, did not show retinitis pigmentosa - a sign considered to precede all others in most patients. ${ }^{217}$ Presentation of an incomplete syndrome is not, however, considered unusual in this disease,$^{2}$ which doubtless contributes to the apparent infrequency with which the diagnosis is made or even considered in childhood.

Opthalmologic disturbances are said to occur in all patients with Refsum's disease ${ }^{2}$ but they may not always be readily apparent, particularly in the early stages. Night blindness, a frequent manifestation of the retinal changes, is not always easily ascertained, particularly in children, and thus may be missed. Retinitis pigmentosa was observed only in case 1; and case 3, which was clinically and biochemically the most florid, showed only retinal changes which could be regarded as precursors of this condition.

At presentation only cases 2 and 3 showed clinical and neurophysiological evidence of a peripheral neuropathy, and only case 3 showed a number of other features commonly observed in patients with Refsum's disease, (ichthyosis, cardiomyopathy, and retinal changes). Reese and Bareta ${ }^{18}$ reported a 
patient who may have a similar phenotype to case 2 , who presented with a peripheral neuropathy at the age of 4 years, but in whom visual changes were not observed until much later.

An affected liver is rare in adult onset Refsum's disease, and we know of only one published report of this ${ }^{19}$ There have been reports, however, of children with Refsum's disease who presented with hepatomegaly. ${ }^{120-23}$ The possibility that the nearly fatal subdural haematoma suffered by case 1 was related to a coagulation defect caused by hepatocellular damage, and severe portal tract fibrosis in case 2 suggests that a phytanic acid oxidase deficiency state should be considered in children who present with unexplained hepatic pathology.

Appreciable concentrations of phytanic acid were found in the liver of case 1 , but not case 2 . Electron microscopy of liver biopsy material from the former showed the trilaminar lamellar profiles seen by Scotto $e t a^{22}$ in their patients, but this was not seen in the liver specimen from case 2. The apparent absence of this feature in case 2 may indicate that appreciable accumulation of lipid may be necessary for the development of lamellar profiles. Although phytanic acid oxidase seems to be confined to mitochondria, ${ }^{24} 25$ in our patient lamellar profiles were most abundant within lysosome like bodies. A possible explanation for this might be that the mitochondrial enzyme defect leads to the initial accumulation of substrate in the cytoplasm, followed by uptake and further accumulation within lysosomes. Biochemical studies on separated subcellular organelles from patients before and after dietary treatment may help to clarify the intracellular events occurring in this disorder.

Our data further highlight the considerable degree of phenotypic variability which exists in patients with phytanic acid oxidase deficiency. It is clear that the spectrum of phenotypes is quite wide and that classic Refsum's disease represents one clinical manifestation of the enzyme deficiency state only. Assuming that the children described by Scotto et al ${ }^{22}$ were deficient in phytanic acid oxidase they clearly represent a group separate from adult Refsum's disease patients. Of the four children we have described, only one (case 1) displays most of the features consistent with Refsum's disease, and while case 4 shows the characteristic dysmorphic features, deafness, and motor and intellectual deterioration of the latter group he does not show the hepatomegaly and retinitis pigmentosa. Case 3 seems to be different again, and may represent an early onset form of classic Refsum's disease.

The nosological relationship of case 2 to all other patients thus far described is not known-it is not clear whether a patient with phytanic acid oxidase deficiency but without a raised plasma phytanate value (in the absence of treatment) should in fact be considered to have Refsum's disease. There is little doubt, however, that a more useful classification of such a clinically diverse group must await a detailed study of the enzyme in normal and mutant cells and tissues.

We thank Mr C. Hann who performed the combined chemical ionisation mass spectrometric analysis and $\mathrm{Dr}$ Leo Sosula who performed the electron microscopy shown in the Figure.

\section{References}

1 Richterich R, Moser M, Rossi E. Refsum's disease (Heredopathia atactica polyneuritiformis). An inborn error of lipid metabolism with storage of $3,7,11,15$ tetramethyl hexadecanoic acid. A review of the clinical findings. Humangenetik 1965;1:322-32.

2 Refsum S. Heredopathia atactica polyneuritiformis. Phytanic acid storage disease (Refsum's disease). In: Vinken PJ, Bruyn GW, eds. Handbook of clinical neurology, metabolic disorders of the nervous system. Amsterdam: North Holland Publishing, 1975:181-229.

${ }^{3}$ Steinberg D. Phytanic acid storage disease: Refsum's syndrome. In: Stanbury JB, Wyngaarden JB, Fredrickson DS, eds. The metabolic basis of inherited disease. New York: McGraw-Hill, 1978:688-706.

4 Refsum S, Solomonsen L, Skatredt M. Heredopathia atactica polyneuritiformis in children. J Pediatr 1949;35:335-43.

5 Richterich R, Rosin S, Rossi E. Refsum's disease (Heredopathia atactica polyneuritiformis). An inborn error of lipid metabolism with storage of $3,7,11,15$-tetramethyl hexadecanoic acid. Formal genetics. Humangenetik 1965;1:333-6.

6 Steinberg D, Mize CE, Avigan J, et al. Studies in metabolic error in Refsum's disease. J Clin Invest 1967;46:313-22.

7 Steinberg D, Herndon JH, Jr, Uhlendorf BW, Mize CE, Milne GWA. Refsum's disease: nature of enzyme defect. Science 1967;156:1740-2.

8 Eldjarn L, Stokke O, Try K. Biochemical aspects of Refsum's disease and principles for the dietary treatment. In: Vinken PJ, Bruyn GW, eds. Handbook of clinical neurology, metabolic disorders of the nervous system. Amsterdam: North Holland Publishing, 1975.

9 Poulos A, Barone E, Johnson DW. Partial synthesis of $\left[1-{ }^{14} \mathrm{C}\right]$ phytanic acid. Lipids 1980;15:19-21.

10 Poulos A. Diagnosis of Refsum's disease using $\left[1-{ }^{14} \mathrm{C}\right]$ phytanic acid as substrate. Clin Genet 1981;20:247-53.

11 Phillipou G, Poulos A. The quantitation of plasma phytanic acid by mass fragmentography. Clin Chim Acta 1976;72:319-25.

12 Folch J, Lees M, Sloane-Stanley G. A simple method for the isolation and purification of total lipids from animal tissue. $J$ Biol Chem 1957;226:497-509.

13 Masters-Thomas A, Bailes J, Billimoria JD, Clemens ME, Gibberd FB, Page NGR. Heredopathia atactica polyneuritiformis (Refsum's disease). Clinical features and dietary management. J Hum Nutr 1980;34:245-50.

14 Gibberd FB, Billimoria JD, Page NGR, Retsas S. Heredopathia atactica polyneuritiformis (Refsum's disease) treated by diet and plasma exchange. Lancet 1979; i:575-8.

15 Herndon JH, Steinberg D, Uhlendorf BW. Refsum's disease. Defective oxidation of phytanic acid in tissue cultures derived from homozygotes and heterozygotes. N Engl J Med 1969;281:1034-8.

16 Menkes JH, Comp. Heredodegenerative disease. In: Text-book of child neurology. Philadelphia: Lea and Febiger, 1974. 
${ }^{17}$ Refsum S. Heredopathia atactica polyneuritiformis (Refsum's disease). Clinical and genetic aspects. In: Dyck PJ, Thomas PK, Lambert EH, eds. Peripheral neuropathy. Philadelphia: WB Saunders, 1975.

${ }^{18}$ Reese H, Bareta J. Heredopathia atactica polyneuritiformis. $J$ Neuropathol Exp Neurol 1950;9:385-95.

19 Kolodny EH, Hass WK, Lane B, Drucker WD. Refsum's syndrome: report of a case including electron microscopic studies of the liver. Arch Neurol 1965;12:583-96.

20 Khalke W. Refsum-Syndrom. Lipoidchemische untersuchengen 9 fällen. Klin Wochenschr 1964;42:1011-6.

21 Richterich R, Van Mechelen P, Rossi E. Refsum's disease (heredopathia atactica). An inborn error of lipid metabolism with storage of $3,7,11,15$ tetramethylhexadecanoic acid. Am J Med 1965;39:230-6.

22 Scotto JM, Hadchouel M, Odievre M, et al. Infantile phytanic acid storage disease, a possible variant of Refsum's disease: three cases including ultrastructural studies of the liver. J Inherited Metab Dis 1980;5:83-90.

${ }^{23}$ Boltshauser E, Spycher MA, Steinmann B, et al. Infantile phytanic acid storage disease: a variant of Refsum's disease. Eur J Pediatr 1982;139:317.

24 Johannessen JV. Electron microscopy in human medicine. Vol. 2: Cellular pathobiology, metabolic and storage diseases. New York: McGraw-Hill International, 1978:39-50.

${ }^{25}$ Tsai SC, Avigan J, Steinberg D. Studies on the $\alpha$-oxidation of phytanic acid by rat liver mitochondria. J Biol Chem 1969;244:2682-92.

Correspondence to Dr A Poulos, Department of Chemical Pathology, The Adelaide Children's Hospital, North Adelaide, South Australia 5006, Australia.

Received 1 December 1983

\section{Personal choice}

\section{Adenoidectomy and glue ear}

The effects of adenoidectomy and adenotonsillectomy on chronic otitis media with effusion that had not responded to medical treatment were studied prospectively in a cohort of 103 children with this condition. The children were allocated randomly to one of three groups-adenoidectomy, adenotonsillectomy, and a no surgery control group. After one year the otitis media had resolved in $72 \%$ of the children undergoing adenoidectomy, in $62 \%$ of the adenotonsillectomy group, and in $26 \%$ of the controls. The effect of adenoidectomy alone was highly significant $(\mathrm{P}<0.001)$ compared with the control group, but tonsillectomy conferred no additional benefit. 